\title{
Scorpions from Mata do Buraquinho, João Pessoa, Paraíba, Brazil, with ecological notes on a population of Ananteris mauryi Lourenço (Scorpiones, Buthidae)
}

\author{
Sidclay C. Dias ${ }^{1}$; Denise M. Candido ${ }^{2} \&$ Antonio D. Brescovit ${ }^{2}$ \\ ${ }^{1}$ Laboratório de Aracnologia, Museu Paraense Emílio Goeldi. Avenida Perimetral 1901, Caixa postal 399, 66017-970 Belém, \\ Pará, Brasil. E-mail: pachistopelma@hotmail.com \\ 2 Laboratório de Artrópodes, Instituto Butantan. Avenida Vital Brasil 1500, 05503-900 São Paulo, São Paulo, Brasil. \\ E-mail: denisecandido@butantan.gov.br; adbresc@terra.com.br
}

\begin{abstract}
Four species of scorpions (Ananteris mauryi Lourenço, 1982, Tityus neglectus Mello-Leitão, 1932, T. pusillus Pocock, 1893 and T. stigmurus (Thorell, 1876)) were collected in the "Mata do Buraquinho", João Pessoa, state of Paraíba, Brazil. Aspects of biology for A. mauryi and new records on the geographic distribution of other species were annotated. Notes on the abundance and sex ratio on $A$. mauryi, the most abundant species in the area, are presented and discussed.
\end{abstract}

KEY WORDS. Arachnida; Atlantic Forest; Neotropical region; new records; population biology.

RESUMO. Escorpiões da Mata do Buraquinho, João Pessoa, Paraíba, Brasil, com notas ecológicas sobre uma população de Ananteris mauryi Lourenço (Scorpiones, Buthidae). Foram coletadas quatro espécies de escorpiões na Mata do Buraquinho, João Pessoa, Paraíba, Brasil (Ananteris mauryi Lourenço, 1982, Tityus neglectus Mello-Leitão, 1932, T. pusillus Pocock, 1893 e T. stigmurus (Thorell, 1876)). Aspectos da biologia de A. mauryi e novos registros de distribuição geográfica das outras espécies foram anotados. Notas sobre a abundância e razão sexual de $A$. mauryi, a espécie mais abundante nessa área, são apresentados e discutidos.

PALAVRAS-CHAVE. Arachnida; biologia populacional; Mata Atlântica; Região Neotropical; registros novos.

\begin{abstract}
The phenology of various arachnids, including scorpions, has been studied in the Neotropical region (WILLIS 1976, ADIs et al. 1989, 1999, HöFer et al. 1996, MarTins et al. 2004). The abundance of these groups depends on many factors such as rainfall, temperature, and resources availability (e.g. food). In tropical systems, food may be a direct measurement of rainfall, since the abundance of insects and rainfall are well related (WOLDA 1978). In some tropical areas, scorpion's activity has been the same year rounding (CANDIDO 1999), due the lack of well established seasons/pluvial regimes. In the Atlantic Forest of Northeastern Brazil, there is no influence of a critical period of warm up or rainy, and two well not determined seasons, a dry and a wet period must influence the abundance of the scorpion fauna.

Studies on distribution and ecology of the scorpion fauna in urban forests are scarce (CRUCITTI et al. 1998, MCInTYRe 1999, 2000). The knowledge on urban scorpions in Brazilian environments is restricted to epidemiology and accident cases. The lack of samplings of the scorpion fauna in urban areas is a problem when dealing with geographical distribution or ecological studies, since there is a misrepresentation in various localities. LOURENÇO (1986a, b, 2004) contributed to the knowledge on the geographical distribution of Neotropical scorpions, but in
\end{abstract}

his papers many localities are not cited, simply due the lack of sampling in urban habitats. The aim of this study is to present new records and biological remarks on the scorpion fauna collected with pitfall traps in an Atlantic Forest in Northeastern Brazil and analyze the abundance and the sex ratio of Ananteris mauryi Lourenço, 1982 in the wet and dry seasons.

\section{MATERIAL AND METHODS}

The "Mata do Buraquinho", is a remnant of Atlantic Forest in João Pessoa, Paraíba, Brazil $\left(07^{\circ} 06^{\prime}\right.$ S, $34^{\circ} 52^{\prime} \mathrm{W}$, Fig. 1). During the construction of the Campus I of the Universidade Federal da Paraíba, in 1970 the BR 230 highway divided the original "Mata do Buraquinho" in two parts, a forest continuum of 471 ha and 11 small fragments within the Campus I area. Currently, there is no connection between the major forest fragment of the "Mata do Buraquinho" and those of Campus I. The Mata do Buraquinho is a typical Northeastern coast rain forest and its flora is composed by trees, shrubs and herbaceous plants with low sub-canopy stratus and almost no lianas.

Samplings were carried out during the dry season of 2003 and wet season of 2004 in the major fragment. Four hundred pitfall traps were installed, 200 in October, 2003, during the 


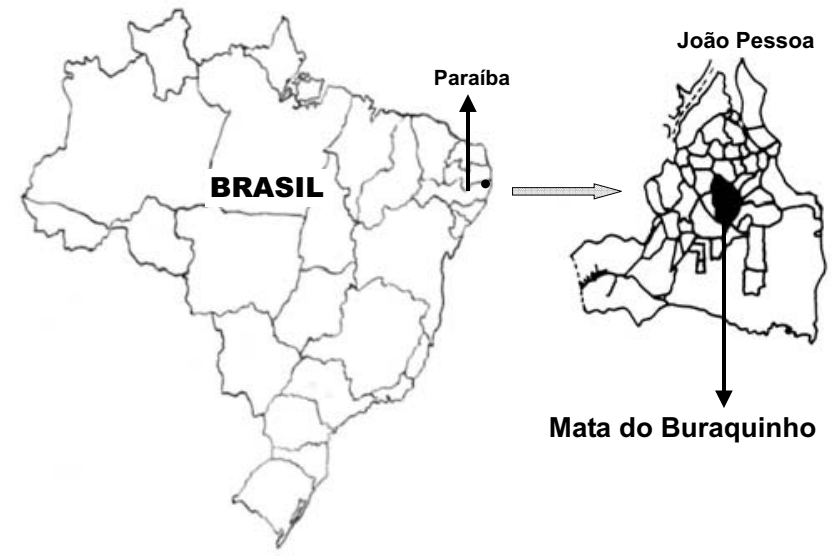

Figure 1. Map showing the localization of Mata do Buraquinho, João Pessoa, Paraíba, in Brazil.

dry season, and 200 in May, 2004, during the wet season. The traps were set for five days and were placed in the same area in both seasons, covering $200 \mathrm{~m}^{2}$. The traps were made out of plastic cups with $5 \mathrm{~cm}$ of opening radius and internal volume of $300 \mathrm{ml}$. In order to reduce the chances of sub or super sampling errors the same sampling effort was make in both periods. Student $t$ tests were performed at 0.05 levels to verify significant differences in abundance between seasons. Chi-squared tests were performed at 0.05 levels to verify the sex ratio. Historical distribution data was obtained in FET et al. (2000). Specimens are deposited in the arachnid collection of the Laboratório de Artrópodes, in the Instituto Butantan, São Paulo (IBSP, curator: A.D. Brescovit).

\section{RESULTS}

A total of 72 specimens, belonging to two genera and four species, were collected: Ananteris mauryi $(\mathrm{n}=66)$, Tityus neglectus Mello-Leitão, 1932 ( $\mathrm{n}=4$ ); T. pusillus Pocock, 1893 (n $=1$ ) and T. stigmurus (Thorell, 1876) $(\mathrm{n}=1)$ (Figs 2-5). A. mauryi was originally described from João Pessoa, from a forest remnant of Campus I of the "Universidade Federal da Paraíba" which is part of the Mata do Buraquinho complex. According to FET et al. (2000) records of this species include only to the states of the Paraíba, and Rio Grande do Norte. Besides this species, the only recorded Ananteris Thorell, 1891 is A. franckei Lourenço, 1982, from the Caatinga of the state of Pernambuco (LOURENÇO 1982).

The three others species belong to the genus Tityus Koch, 1836. This genus includes 160 species, of which more than fifty have been recorded from Brazil and 15 from the Northeastern. T. neglectus is a very common scorpion in northeastern Brazil, occurring in almost all states (LOURENço \& EICKSTEDT 1988). Nevertheless this is the first record from the state of Paraíba. T. pusillus has also been recorded from almost all northeastern states. In Paraíba it was know only from the area of
Mamanguape $\left(06^{\circ} 41^{\prime} \mathrm{S}, 35^{\circ} 10^{\prime} \mathrm{W}\right)$, and is now recorded for the first time in João Pessoa. T. stigmurus has been previously recorded from João Pessoa, Paraíba and the states of Bahia, Sergipe, Alagoas, Pernambuco, Rio Grande do Norte, Ceará, and Piauí.

The abundance of $A$. mauryi was different between two seasons. Fifty-four scorpions (27 males, 22 females and five juveniles) were collected during dry season, and 12 (five males, four females and three juveniles) during the wet season. The abundance of specimens collected during the dry season was significantly greater than that of wet season $(\mathrm{t}=-13.62$; d.f. $=$ 64; $\mathrm{p}<0.01$ ). The sex ratio was 1:1 (Fig. 6), with Chi-Square $\left(\chi^{2}\right)$ not significant at 0.05 level in both seasons (dry $\chi^{2}=0.51$, d.f. $=1 ; \mathrm{p}=0.475$ and wet $\chi^{2}=0.11$, d.f. $=1 ; \mathrm{p}=0.739$ ).

\section{DISCUSSION}

The Tityus species collected during this study are well distributed in northeastern Brazil. According to Lourenço (1986b), T. pusillus might be an endemic species of the "Pernambuco area of endemism". However, its geographical distribution has already been expanded to the states of Bahia, Sergipe, and Piauí (see FET et al. 2000).

Tityus stigmurus is the scorpion responsible for the highest number of accidents in northeastern Brazil (BIONDI-DE-QUEIROZ 1996, Lourenço \& Eickstedt 2003). The Mata do Buraquinho is a large forest enclave surrounded by human habitations. Therefore this species can represent an epidemiological problem. The loss of the natural habitats of T. stigmurus could cause this species to invade the houses that surround the border of the forest, causing the increase in the number of accidents.

Ananteris is a Neotropical genus that is recorded in almost all South America, and in Brazil is distributed in the Amazon, Cerrado, Caatinga, and Atlantic Forest regions (Lourenço 2004). Since $A$. mauryi had only been recorded from the "Pernambuco area of endemism" (sensu Silva \& Tabarelli 2000), LOURENÇO (1986b) stated that this species was isolated during a dry period in the refuge of Atlantic Forest. This species has also been recorded from to two localities from Sergipe and deposited in the Instituto Butantan. The "endemism hypotheses" to the Ananteris group of the Northeastern will have to be revised.

ADIs et al. (1999) recorded that the total catches of specimens of a species of Schizomida in the Central Amazonia during dry and rainy season is the same. Martins et al. (2004) showed that one species of Solifugae in the open forest has two activity peaks during the year: the highest peak occurred in the dry season and the lowest in the wet season. For arachnids, phenology can be observed as a function of the climate variation of a habitat or a function of reproductive biology species-specific. The climate of the Atlantic Forest of northeastern Brazil show one peak of rainy. According to our data, the abundance of $A$. mauryi increases during the dry season. These facts are different with the results obtained for others arachnids, in which abundance was observed to be lower dur- 

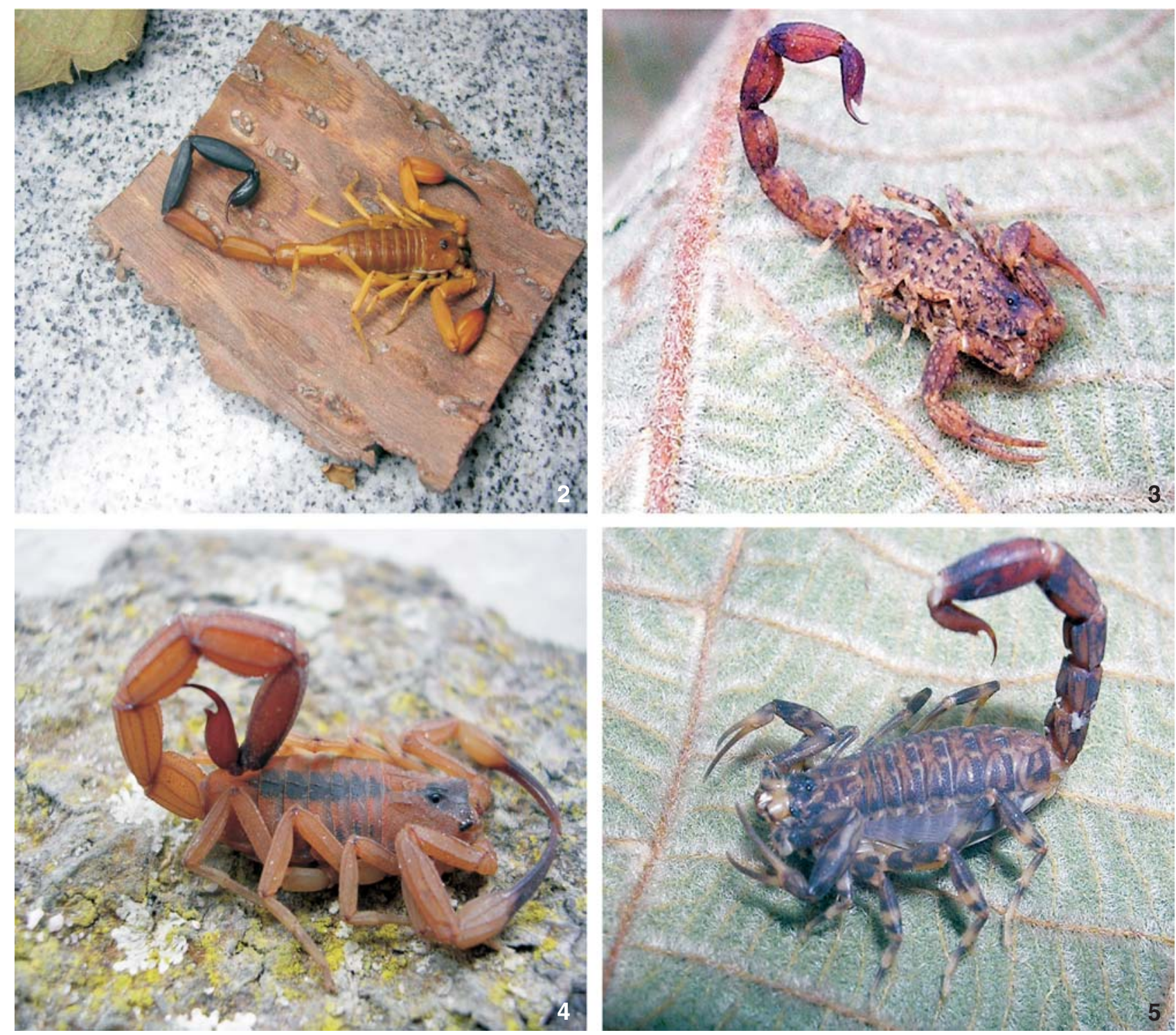

Figures 2-5. (2) Tityus neglectus, dorsal view; (3) T. pusillus, dorsal view; (4) T. stigmurus, dorsal view; (5) Ananteris mauryi dorsal view.

ing dry periods (WiLLIs 1976, Adis et al. 1987a, b). On the other hand, CANDIDO (1999) state that there is no critical period for the abundance of scorpions. PolIs \& SIssom (1990) stated that the sex ratio in non-parthenogenetic scorpions is $1: 1$. For the population of $A$. mauryi in both seasons, the sex ratio was $1: 1$, corroborating the literature data for Buthidae (PoLIs \& SIssom 1990). Polis (1990) stated that the mortality in some species of scorpions is a function presented by a survivorship curve, and that there is a period of constant, low mortality, during the months of immaturity. Apparently, the population of A. mauryi during the wet season can be decreased for this reason conformed appointed by PoLis (1990) since that this work was con-

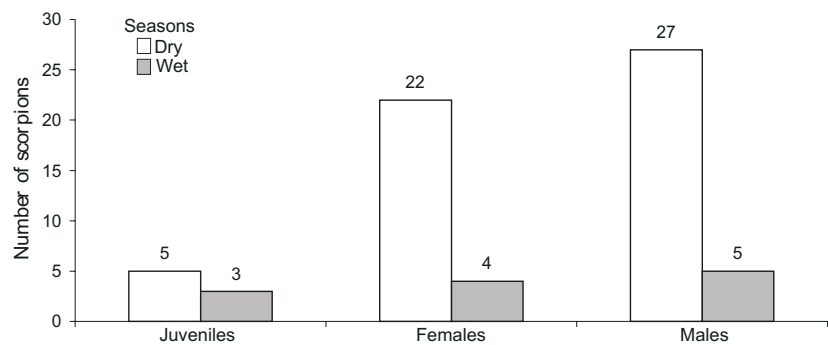

Figure 6. Proportion of juveniles (1), females (2) and males (3) of Ananteris mauryi by each year season in Mata do Buraquinho, João Pessoa, Paraíba (dry, white bars; wet, hatched bars).

Revista Brasileira de Zoologia 23 (3): 707-710, setembro, 2006 
ducted in a period with a gap of seven months between the collections periods. More studies on seasonality of $A$. mauryi will be important to verify if this is not is an isolated event.

\section{ACKNOWLEDGMENTS}

To Cristina A. Rheims, Marcelo O. Gonzaga, Ricardo P. da Rocha for the sugestions on the manuscript. To CNPq (To CNPq (to ADB, and SCD that grants a PhD scholarship) and Fapesp (99-05546-8) for financial supported. This study is part of BIOTA/FAPESP - The Biodiversity Virtual Institute Program (www.biotasp.org.br).

\section{REFERENCES}

Adis, J.; J.W. Morais \& E.F. Ribeiro. 1987a. Vertical distribution and abundance of arthropods in the soil of a Neotropical Secondary Forest during the dry season. Tropical Ecology, Varanasi, 28: 174-181.

Adis, J.; J.W. Morais \& H.G. Mesquita. 1987b. Vertical distribution and abundance of arthropods in the soil of a Neotropical Secondary Forest during the rainy season. Studies on Neotropical Fauna and Environment, Tübigen, 22: 189-197.

Adis, J.U.; N.I. Platnick; J.W. Morais \& J.M.G. Rodrigues. 1989. On the abundance and ecology of Ricinulei (Arachnida) from Central Amazonia, Brazil. Journal of New York Entomological Society, New York, 97: 133-140.

AdIs, J.; J. RedDelL; J. CoKendolpher \& J.W. MoRAis. 1999. Abundance and phenology of Schizomida (Arachnida) from a primary upland Forest in Central Amazônia. The Journal of Arachnology, Denver, 27: 205-210.

BIONDI-DE-QUEIROZ, I. 1996. Estudo Retrospectivo do Escorpionismo na Região Metropolitana de Salvador (RMS) - Bahia, Brasil. Sitientibus, Feira de Santana, 15: 273-285.

CANDIDO, D.M. 1999. Escorpiões, p. 25-34. In: C.R.F. BRANDÃo \& E.M. CAnCelo (Eds). Invertebrados terrestres. Biodiversidade do Estado de São Paulo. Síntese do conhecimento ao final do século XX. São Paulo, FAPESP, vol. 5, 279p.

Crucitti, P.; M. Malori \& G. Rotella. 1998. The scorpions of the urban habitat of Rome (Italy). Urban Ecosystems, Heidelberg, 2: $163-170$.

Fet, V.; W.D. Sissom; G. Lowe \& M.E. Braunwalder. 2000. Catalog of the Scorpions of the World (1758-1998). New York, New York Entomological Society, 690p.

HÖFER, H.; E. WOLLSCHEID \& T. GASNIER. 1996. The relative abundance of Brortheas amazonicus (Chactidae, Scorpiones) in different habitat types of a Central Amazon Rainforest. The Journal of Arachnology, Denver, 24: 34-38.
LOURENÇO, W.R. 1982. Révision du genre Ananteris Thorell, 1891 (Scorpiones, Buthidae) et description de six espèces nouvelles. Bulletin Museum Natural History, Paris, 4: 119-151.

LOURENÇO, W.R. 1986a. Diversite de la faune scorpionique de la Region Amazonique; centres d'endemisme; nouvel appui a la theorie des refuges forestiers du pleistocene, p. 231-237. In: Actas del X Congreso Internacional de Aracnología. Jaca, vol 1.

LOURENÇO, W.R. 1986b. La vicariance biogéographique chez les scorpions Néotropicaux. Bulletin of Ecology, New Jersey, 17: 161-172.

LOURENÇO, W.R. 2004. List of the species of Ananteris Thorell, 1891 (Scorpiones, Buthidae) with the description of a new species from the State of Bahia, Brazil. Revista Ibérica de Aracnología, Zaragoza, 10: 163-166.

Lourenço, W.R. \& V.R.D. von Eickstedt. 1988. Sinopse das espécies de Tityus do nordeste do Brasil, com a redescrição de $T$. neglectus Mello-Leitão (Scorpiones, Buthidae). Revista Brasileira de Biologia, Rio de Janeiro, 5: 399-408.

Lourenço, W.R. \& V.R.D. von Eickstedt. 2003. Escorpiões de Importância Médica, p. 182-197. In: J.L.C. CARDOSO; F.O.S. FranÇa; F.H. Wen; C.M.S. Málaque \& V. Haddad JR. (Eds). Animais Peçonhentos no Brasil: Biologia, Clínica e Terapêutica dos Acidentes. São Paulo, Sarvier, 468p.

Martins, E.G.; V. Bonato; G. Machado; R. Pinto-da-Rocha \& L.S. Rocha. 2004. Description and ecology of a new species of sun spider (Arachnida: Solifugae) from the Brazilian Cerrado. Journal of Natural History, London, 38: 2361-2375.

MCINTYRE, N.E. 1999. Influences of urban land use on the frequency of scorpion stings in the Phoenix, Arizona, metropolitan area. Landscape and Urban Planning, Texas, 45: 47-55.

MCINTYRe, N.E. 2000. Ecology of urban arthropods: A review and a call to actions. Annals of Entomological Society of America, Lanham, 93: 825-835.

Polis, G.A. 1990. Ecology, p. 247-293. In: G.A. Polis (Ed.). The Biology of Scorpions. Stanford, University Press, 587p.

Polis, G.A. \& W.D. Sissom. 1990. Life History, p. 161-223. In: G.A. Polis (Ed.). The Biology of Scorpions. Stanford, University Press, $587 \mathrm{p}$.

Silva, J.M.C. \& M. Tabarelli. 2000. Tree species impoverishment and the future flora of the Atlantic forest of northeast Brazil. Nature, London, 404: 72-74.

WILLIS, E.O. 1976. Seasonal changes in the invertebrate litter fauna on Barro Colorado Island, Panamá. Revista Brasileira de Biologia, Rio de Janeiro, 36: 643-657.

WolDA, H. 1978. Seasonal fluctuations in rainfall, food and abundance of tropical insects. Journal of Animal Ecology, London, 47: 369-381.

Received in 13.X.2005; accepted in 17.VIII.2006. 